\title{
COSMETIC PRODUCTS AS AN OBJECT OF TECHNICAL REGULATION OF THE MINISTRY OF HEALTH. DEVELOPMENT OF A METHODOLOGY FOR THE IMPLEMENTATION OF THE TECHNICAL REGULATIONS
}

\author{
Iryna Kazakova, Svitlana Kovalenko, Viacheslav Lebedynets, Viktoriya Kazakova, \\ Daria Bondarenko
}

From 2021, cosmetic products are subject to technical regulation of the Ministry of Health, which is responsible for ensuring the implementation of Technical Regulations, approval of guidelines for their application, national standards in accordance with the requirements of Technical Regulations. It was adopted in early 2021. For the first time in Ukraine, the technical regulations for cosmetic products apply to cosmetic products the principles of technical regulation, powers to comply with which are vested in the relevant Ministry of Health.

The aim of this work is to develop a methodology for implementing the Technical Regulations for cosmetic products as an object of authority of the Ministry of Health.

As research materials the processes of technical regulation of cosmetic products are studied, logical, investigation methods of research, and also a method of the content analysis are used.

Results. An analysis of the practice of regulating the circulation of cosmetic products in a number of foreign countries, identified and systematized potential risks in the implementation of the principles of its technical regulation. Based on the analysis of causal relationships in the process of implementing the requirements of the Technical Regulations for cosmetic products, the methodology of its practical application is proposed.

Conclusions. The tendencies of regulatory policy in relation to cosmetic products in a number of foreign states and Ukraine are established. The analysis of the main provisions of the Technical Regulations for cosmetic products is carried out and the methodology of its introduction is developed

Keywords: technical regulation, cosmetic products, Technical regulations for cosmetic products, standards, quality management system

\footnotetext{
How to cite: 41-48. doi: http://doi.org/10.15587/2519-4852.2021.243123

(C) The Author(s) 2021

This is an open access article under the Creative Commons CC BY license hydrate
}

Kazakova, I., Kovalenko, S., Lebedynets, V., Kazakova, V., Bondarenko, D. (2021). Cosmetic products as an object of technical regulation of the ministry of health. development of a methodology for the implementation of the technical regulations. ScienceRise: Pharmaceutical Science, 5 (33),

\section{Introduction}

The trend of development of the world cosmetic industry is the orientation of the market to multifunctional products, which combines cosmetic properties and therapeutic activity, is safe and environmentally friendly for humans and the environment $[1,2]$. At the same time, modern cosmetics are characterized by high potential insecurity in daily contact with the skin, as a result of which regulators set stricter standards for cosmetic products (CP) and improve methods for assessing its quality and safety. The activity of the cosmetic industry requires a dynamic revision of the principles of technical regulation of products, which is relevant at the stage of harmonization of industry legislation in accordance with international standards [3]. In fulfilment of obligations with the EU, 20.01.21 Resolution of the Cabinet of Ministers of Ukraine (CMU) No. 65 approved the Technical Regulations for cosmetic products (hereinafter - the Regulations) [4]. The adopted document is harmonized in accordance with the requirements of the European "Regulation (EC) No. 1223/2009. European parliament and of the council of 30 November 2009 on cosmetic products" [5] and radically changes the rules of CP turnover in the
Ukrainian market. According to the adopted rules, CP is regulated as an object of technical regulation by the Ministry of Health of Ukraine (MHU), and has new requirements for quality, safety and efficiency, control over which is entrusted to the State Service of Ukraine for Medicines and Drug Control (State Service for Medicines). Due to the transfer of CP to the jurisdiction of the health care system authorities, the prompt and effective implementation of the requirements of the Regulation in the state regulatory policy and the activities of business entities engaged in all spheres of CP's life is of particular importance. Thus, the development of a methodology for the effective implementation of the Regulation, taking into account the current state of the national licensing system and the sectoral legal framework, is an urgent and timely task.

The problem of developing mechanisms for introducing the requirements of the Regulation into the activities of the perfumery and cosmetic industry has not yet become a subject of consideration by Ukrainian scientists. The authors of the publications study the issues of ensuring the quality and safety of $\mathrm{CP}$ [6], the functioning of the cosmetic market $[7,8]$, technical regulation of the 
industry [9]. Foreign scientists analyze the prospects for improving the technical regulation of the industry [10], introducing modern methods for assessing $\mathrm{CP}[11,12]$ and improving its quality and safety [13]. The analysis of scientific works on the subject under study demonstrates the absence of domestic publications on the development of a methodology for the implementation of Technical Regulations for cosmetic products.

The aim of the research - development of a methodology for the implementation of Technical Regulations for cosmetic products as an object of authority of the Ministry of Health.

\section{Research planning (methodology)}

For planning research, the following algorithm of actions was developed:

I stage. Study of the current state of technical regulation of $\mathrm{CP}$ turnover in foreign countries.

1.1 Analysis of the current state of the technical regulation of CP turnover in the USA, China, Japan, India, RF.

1.2. Study of the practice of implementation of the Technical Regulations for cosmetic products in the European Union.

II stage. Analysis of the Technical Regulations for cosmetic products.

2.1. Determination of potential risks in the implementation of Technical Regulations for cosmetic products.

2.2. Analysis and systematization of cause-andeffect relationships of the I-III levels in the process of implementing the requirements of the Regulation on cosmetic products.

III stage. Development of a methodology for the implementation of Technical Regulations for cosmetic products.

3.1. Development of recommendations for an action plan to implement the requirements of the Technical Regulations for cosmetic products.
3.2. Development of a methodology for the implementation of Technical Regulations for cosmetic products.

\section{Materials and methods}

The work used logical, research methods, as well as the method of content analysis, which were used to scientifically reproduce the dynamics of the development of the perfumery and cosmetic industry, conceptualize the study of the sectoral legal framework with the aim of further meaningful interpretation of the revealed patterns. The method of K. Ishikawa was applied to establish cause-and-effect relationships in the study of potential risks; to develop a methodology for the implementation of the Regulation, the methods of process and system approaches were applied.

\section{Research results}

The initial stage of the research was to study the state of the practice of technical regulation of CP turnover in countries with a developed cosmetic market - the European Union (EU), the USA, India, China and Japan, the Russian Federation over the past three years. The legal support of the CP turnover control system in foreign countries is represented by various legislative acts and has comparable regulatory requirements, which must guarantee the basic principles - quality, safety and efficiency of products. The results of the analysis of the normative documentation governing the $\mathrm{CP}$ circulation rules in the EU countries [14, 15], the USA [16], China $[17,18]$, Japan [19, 20], India [21], RF [22], indicate that in all studied countries, various mechanisms for the implementation of regulatory policies in relation to cosmetic products are regulated. But, despite the lack of global harmonization of regulatory requirements, it is imperative to ensure the safety of CP for consumer health. A comparative analysis of the requirements of the regulatory framework of foreign countries for the safety of cosmetics is presented in Table 1.

Table 1

Comparative analysis of the regulatory framework governing $\mathrm{CP}$ safety requirements in foreign countries

\begin{tabular}{|c|c|c|}
\hline Countries & $\begin{array}{c}\text { Authorized bodies; the legis- } \\
\text { lative framework }\end{array}$ & $\mathrm{CP}$ safety assessment regulation \\
\hline 1 & 2 & 3 \\
\hline $\begin{array}{l}\text { EU coun- } \\
\text { tries }\end{array}$ & $\begin{array}{l}\text { National bodies of the coun- } \\
\text { tries of the commonwealth; } \\
\text { Regulation (EU) No } \\
1223 / 2009 \text { of the European } \\
\text { Parliament of the European } \\
\text { Council on cosmetic prod- } \\
\text { ucts, } 2009\end{array}$ & $\begin{array}{l}\text { The safety of CP is confirmed by a safety report, which contains: Quantitative } \\
\text { and qualitative composition of the product; Physicochemical characteristics and } \\
\text { product stability; Microbiological quality of the product; Impurities and prod- } \\
\text { uct packaging material information; Predictable product use; The impact of the } \\
\text { product and substances in its composition; Toxicological profile of substances; } \\
\text { Adverse effects and serious adverse effects of the product; Product information. } \\
\text { Research must be carried out in a GLP certified laboratory. A clinical study } \\
\text { of a group of volunteers is used to assess the irritant and sensitizing effect of } \\
\text { the product. The product dossier includes report data, compliance with GMP } \\
\text { requirements, etc. }\end{array}$ \\
\hline USA & $\begin{array}{l}\text { FDA; } \\
\text { Federal Food, Drug, and } \\
\text { Cosmetic Act), (FD \& C Act, } \\
\text { sec. 201 (and) part 21, chap- } \\
\text { ter IX, subsection VI, 1938r. }\end{array}$ & $\begin{array}{l}\text { US regulations do not specify specific requirements for testing prod- } \\
\text { ucts/ingredients. The FDA recommends that manufacturers perform the tests } \\
\text { necessary to ensure the safety of their products and ingredients. The safety of a } \\
\text { product could be confirmed by: using existing toxicological test data for indi- } \\
\text { vidual ingredients and similar product formulations; performing any additional } \\
\text { toxicological and other tests. GMP guidelines have recommendatory character. }\end{array}$ \\
\hline
\end{tabular}




\begin{tabular}{|c|c|c|}
\hline 1 & 2 & 3 \\
\hline China & $\begin{array}{l}\text { State Administration of Mar- } \\
\text { ket Regulatory (SAMR); } \\
\text { National Medical Products } \\
\text { Administration (NMPA); } \\
\text { Regulation of Cosmetic Su- } \\
\text { pervision and Administration } \\
\text { Regulation (CSAR), 2021г. }\end{array}$ & $\begin{array}{l}\text { Product safety requirements depend on its status - the declaration of special } \\
\text { use cosmetics (SUC) is allowed after testing its safety and effectiveness in } \\
\text { accordance with national standards. Applicants must submit research data on } \\
\text { product performance evaluation on the dedicated NMPA website. } \\
\text { The SUC dossier should include: the name of the product, a complete list of } \\
\text { ingredients; safety assessment documentation; test reports; compliance with } \\
\text { GMP requirements, etc. } \\
\text { Evaluation of effectiveness can be based on literature data, data from effec- } \\
\text { tiveness studies (including human trials), and consumer tests. }\end{array}$ \\
\hline Japan & $\begin{array}{c}\text { Ministry of Health, Labor and } \\
\text { Welfare; } \\
\text { Law on Quality Assurance, } \\
\text { Efficacy and Safety of Me- } \\
\text { dicinal and Medical Devices } \\
\text { (PMDL) } 2019\end{array}$ & $\begin{array}{l}\text { In the process of preclinical testing of a product, its quality, efficacy and } \\
\text { safety must be guaranteed. The safety report should contain: results of toxici- } \\
\text { ty, carcinogenicity, local irritant, phototoxicity testing, HRIPT testing; a } \\
\text { report on the effectiveness and functionality of the product is also required. } \\
\text { MHLW Technical Guidelines for the Safety Assessment of Quasi-Medicines } \\
\text { and Cosmetics dated } 04.22 .21 \text { requires testing for primary and cumulative } \\
\text { skin irritation. } \\
\text { Production requirements are regulated by the standards: Good Quality Prac- } \\
\text { tice, 2014; Good Vigilance Practice, } 2017 \text {; GMP Ministerial Ordinance; } \\
\text { Submission Documents for Application of GMP Compliance Inspection, } \\
2019\end{array}$ \\
\hline India & $\begin{array}{l}\text { Central Organization for the } \\
\text { Oversight of Medicines } \\
\text { Standards (CDSCO); } \\
\text { The Cosmetics Rules } 2020 .\end{array}$ & $\begin{array}{l}\text { The Cosmetics Rules } 2020 \text { sets out the regulatory requirements for manufac- } \\
\text { turing, testing, labelling, importing, registering and selling cosmetics in India. } \\
\text { The production and import of "new" cosmetics requires prior approval from } \\
\text { CDSCO and the provision of safety and efficacy data. The safety of new } \\
\text { cosmetics is tested by the manufacturer in accordance with IS 4011: } 2018 \\
\text { Test Methods for Evaluating the Safety of Cosmetics. }\end{array}$ \\
\hline $\mathrm{RF}$ & $\begin{array}{l}\text { National authorities of the } \\
\text { Eurasian Customs Union; } \\
\text { Technical Regulations of the } \\
\text { Eurasian Customs Union "On } \\
\text { the safety of perfumery and } \\
\text { cosmetic products" } \\
\text { (TR CU 009/2011) }\end{array}$ & $\begin{array}{l}\text { TR CU 009/2011 provides identification requirements; CP safety: composi- } \\
\text { tion requirements; physicochemical, microbiological, clinical toxicological } \\
\text { indicators; toxic elements; production; packaging and CP marking. } \\
\text { Confirmation of the consumer properties of CP can be carried out: accord- } \\
\text { ing to the results of research on volunteers and / or sample models, by in- } \\
\text { strumental methods, based on scientific data for the ingredients in the CP } \\
\text { composition. }\end{array}$ \\
\hline
\end{tabular}

The results of the study indicate that in the studied foreign countries, the practice of ensuring the safety of $\mathrm{CP}$ has been developed and is being improved as one of the main conditions for its placement on the market.

Evaluating the experience of foreign countries, special attention was paid to the practice of regulating $\mathrm{CP}$ turnover in the EU, since the Regulation was developed in accordance with the norms of European legislation European Cosmetic Regulation No. 1223/2009. The objects of the European Cosmetic Regulation are systematized in Fig. 1.

European Cosmetic Regulation No. 1223/2009 contains requirements for the specified subjects of regulation, which cover all the processes of the product life cycle presented in the diagram (Fig. 2.).

In order to fulfil the requirements of European Cosmetic Regulation No. 1223/2009, for each subject of regulation, the relevant standards and guidelines are applied, establishing the order of regulated procedures.

The analysis of the Regulations established that the content, form and structure of the normative legal act confirms its compliance with European Cosmetic Regulation No. 1223/2009 and the requirements of the Law of Ukraine "On Technical Regulations" [23]. At the same time, it should be noted that the norms of technical regulation are being introduced into the practice of CP turnover for the first time, in connection with which the Regulation provides for a "transitional" period of entry into force - 18 months from the date of publication of the decree. The task of the "transitional" stage is to formulate the main problematic issues in the implementation of the Regulation and develop a methodology for its implementation.

In order to establish a set of factors capable of influencing the implementation of the Regulation, we identified possible risks and studied the possibilities of their elimination/minimization. When analyzing the prospects for the implementation of the requirements of the Regulation, the results of previous studies on this issue were used [24, 25]. The following were identified as the main reasons that could affect the implementation of the Regulation - organizational and managerial actions, personnel, financial, regulatory and legal support, and also took into account the influence of the external factor. The use of the instrumental method of $\mathrm{K}$. Ishikawa made it possible to clearly demonstrate the scheme of probable cause-and-effect relationships of the causes of the I - III levels in the process of implementing the requirements of the Regulations (Fig. 3). 


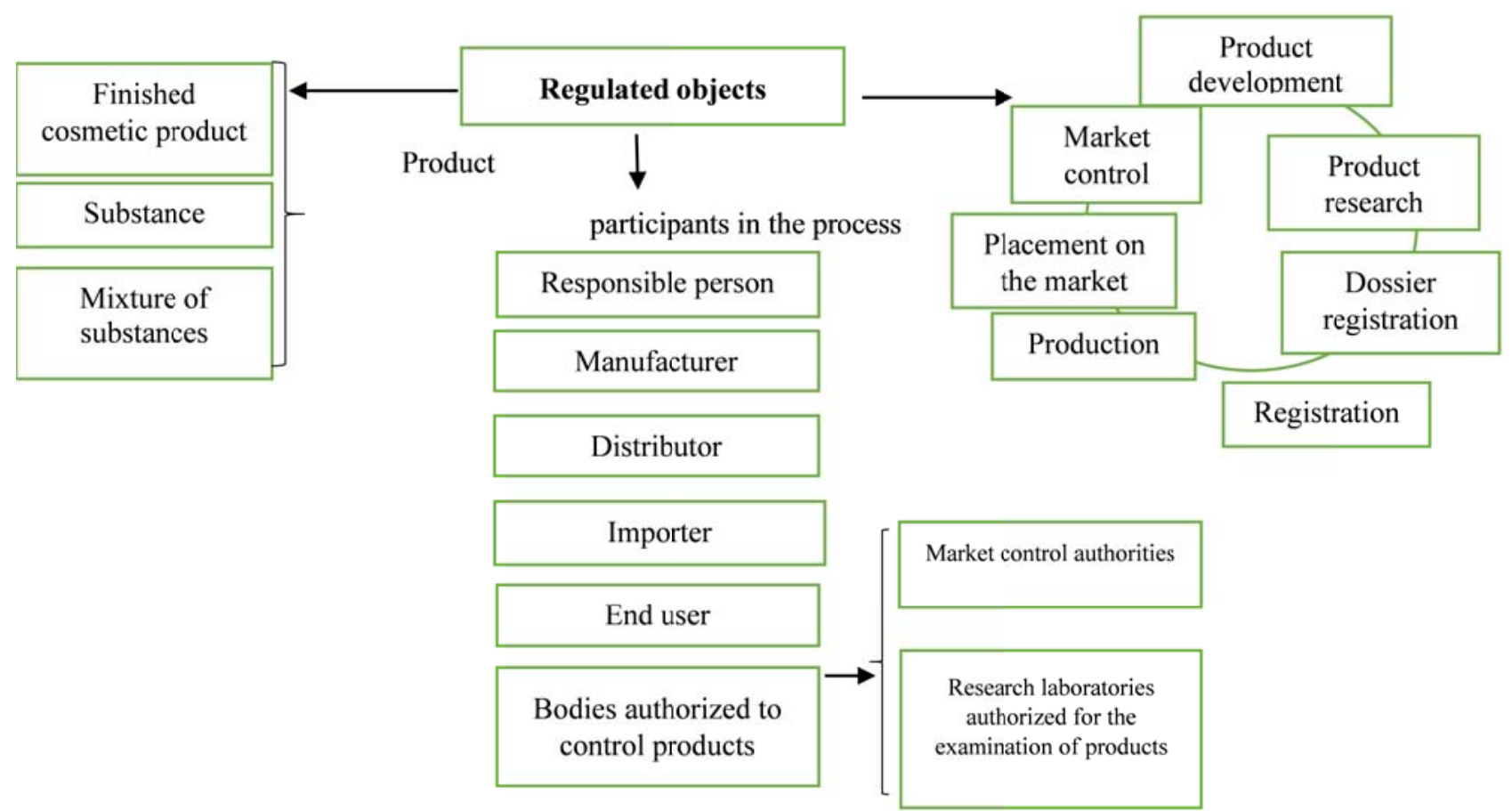

Fig. 1. Subjects of regulation of the European Cosmetic Regulation No. 12:23/2009

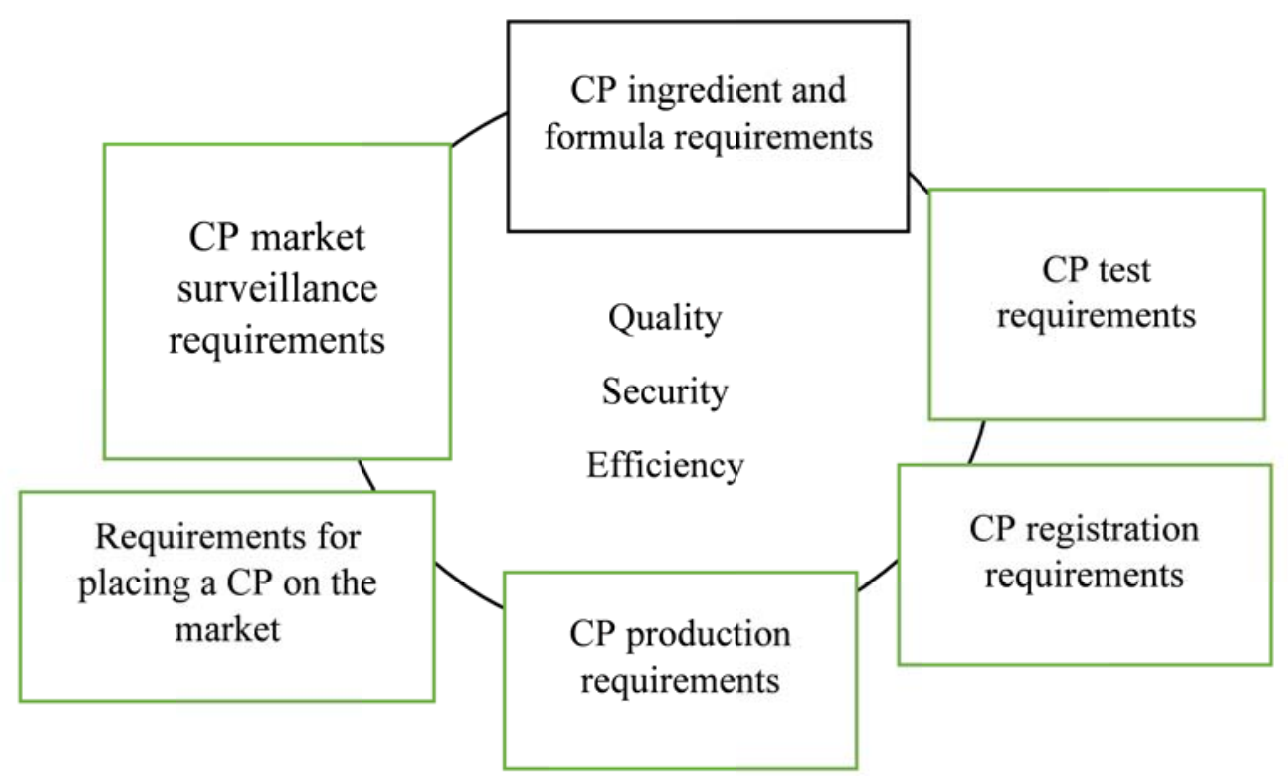

Fig. 2. Basic requirements of European Cosmetic Regulation No. 1223/2009 to CP circulation processes

As follows from Fig. 3, the main reasons depend on a set of factors that could affect the effectiveness of the process. With regard to the main reasons, the factors of secondary influence were systematized - the creation of a management system, legal support of the status and educational training of participants in the processes, norm-setting activities for the standardization of criteria, methods, control procedures, etc. result as a whole.

The identification of potential risks and their systematization were used in the development of an action plan for the implementation of the Regulation. The priority actions at the stage of formation of conditions for the implementation of the Regulation should be the creation of a vertical of administrative management. To implement an effective management policy, a state structure is required, authorized to coordinate the actions of all par- ticipants in the circulation of cosmetic products in the consumer market. Taking into account the powers of the Ministry of Public Health in this area of activity, it could be either a functioning structural unit endowed with additional functions within a line ministry, or a newly created body of similar subordination. In the process of post-marketing control, it is necessary to provide the legal basis for the State Medicines Service to carry out the functions of market contriol over $\mathrm{CP}$ - to make the necessary changes to the current regulatory legal acts. The procedure of cosmetological supervision in the process of post-marketing control in the field of managerial actions requires regulation of the order of interaction of all participants in the process - responsible persons, distributors, employees of healthicare institutions and enterprises providing cosmetic services to the population in 
terms of establishing undesirable effects and making decisions on their corrected. The action plan for the provision of human resources in the field of public administration should initially provide for the definition of the range of powers of officials and their professional retraining. The introduction of new participants - an expert and a responsible person - into the processes of product turnover requires the authorized structures to resolve the issue of the legal justification of their activities. It should also be noted the level of regulated powers of CP distributors, who are also responsible participants in the processes of product turnover, in the event of inconsistencies in their functioning, they are obliged to interact with responsible persons and the state body of market supervision. In this regard, the authority of CP distributors also requires approval of a protocol of their necessary actions.

\section{I.Human resourcing I. Organizational and managerial actions}

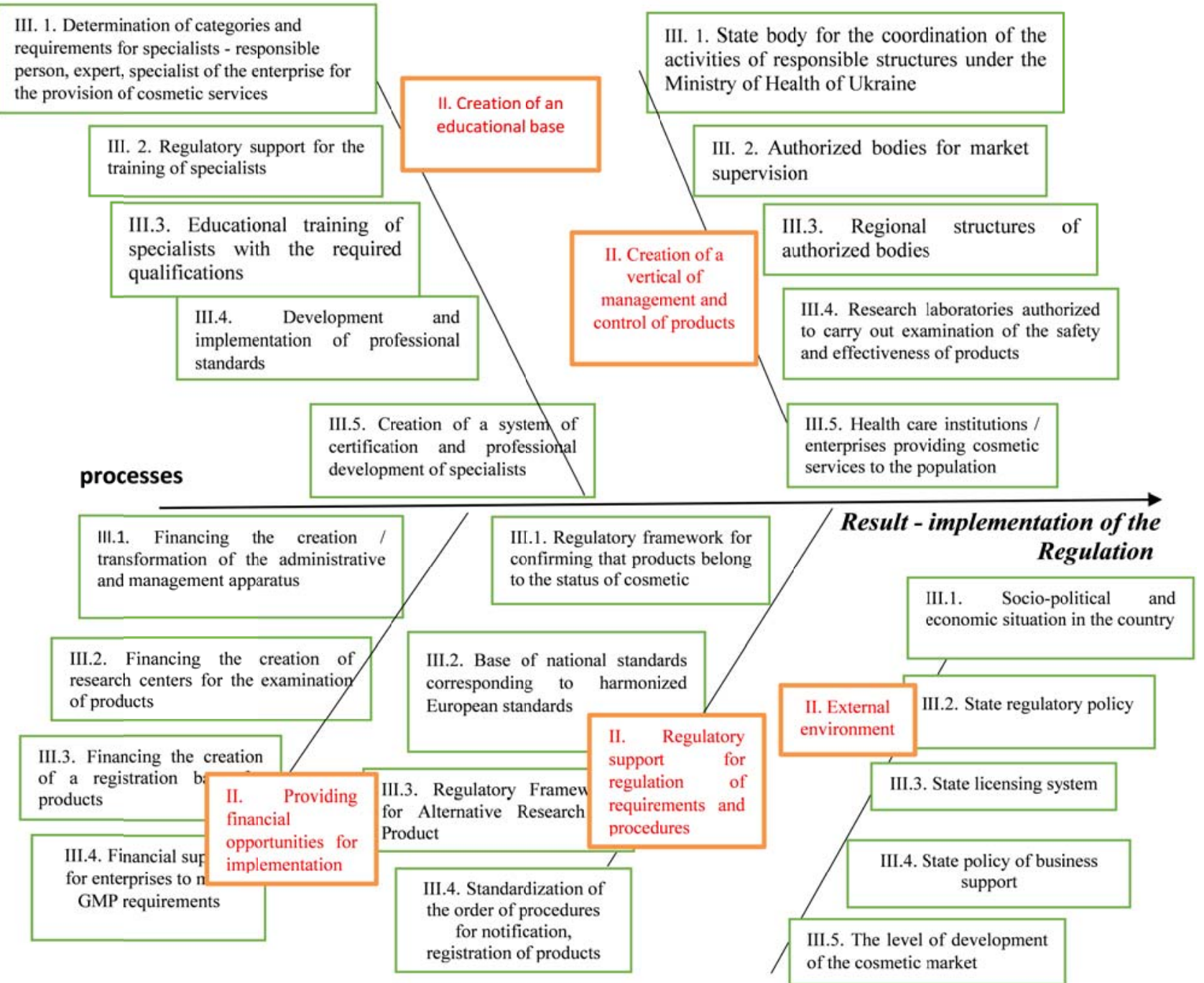

Financial security Legal and regulatory support

External environment

Fig. 3. Diagram of causal relationships of I-III levels in the process of implementing the requirements of the Regulations

The action plan in the field of regulatory support provides for the abolition of regulatory legal acts that duplicate the requirements of the Regulation, as well as amending the current legislative documents in order to bring them in line with the provisions of the Regulation. The process of harmonization of national and European legislation provides for a set of procedures aimed at creating the necessary regulatory framework, the compliance with which gives the presumption of product conformity. During the "transitional" period, a package of national standards should be adopted that regulate the requirements for product testing methods that guarantee its quality, efficiency and safety. When implementing the requirements of European legislation into Ukrainian law, it is necessary to adopt documents regulating the rules for determining the status of cosmetic products and the reliability of claims about them for the consumer. Taking into account the novelty of the regulatory legal document, in order to better adapt the participants in the process of circulation of cosmetic products to the new requirements, it seems appropriate to provide them with methodological recommendations on the order of implementation of all processes required by the Regulation. It is also necessary to revise the practice of adopting standards by the method of confirmation / translation, which are not adapted to the real conditions of the cosmetic market. An important condition for the implementation of the Regulation in the activities of all participants in the 
turnover of products is the timely formation of an information database (chemical ingredients, product files, the register of responsible persons) and ensuring its availability on the portals of the Ministry of Health.

Analyzing the chain of potential risks in the process of implementing the requirements of the Regulation, the main reason for their occurrence should be noted - the lack of a methodology for the implementation of this regulatory legal act. It is necessary to prevent potential risks at the stage of document development, which will minimize efforts to implement it and significantly shorten the "transition" period. Considering that today the Regulation is at the stage of a "transitional" period for its implementation, it seems appropriate to develop a methodology for the implementation of the document's requirements into the activities of the objects of its regulation. The proposed methodology for the implementation of the Regulation is based on the application of the principles of the process approach when formulating procedures for its implementation at all stages of product turnover, and can be represented by the following algorithm:

1.1. To develop a strategy for the development of the national perfumery and cosmetics industry as a socially significant and investment-attractive type of economic activity. The implementation period is November 2021. Responsible person - Ministry of Health, Ministry of Economy, professional public organizations;

1.2. Conduct an analysis of the national legal framework in force in the perfumery and cosmetic industry in order to determine the regulatory resource that ensures the standardization of the quality and safety of cosmetic products. Implementation period - October 2021. Responsible person - Ministry of Health, Ministry of Economy, State Enterprise "Ukrainian Scientific Research and Training Center for Standardization, Certification and Quality Problems" (UkrNDNC);

1.3. Conduct an analysis of European legislation governing the requirements for the technical regulation of cosmetic products. The implementation period is November 2021. Responsible person - Ministry of Health, Ministry of Economy;

1.4. Develop a program of action for the implementation of European legislation in the normative legal acts of Ukraine. The implementation period is December 2021. Responsible person - Ministry of Health, Ministry of Economy, UkrNDNC;

1.5. Develop an action plan for the adoption of national standards, compliance with which provides a presumption of conformity of products with European legislation. The implementation period is January 2022. Responsible person - Ministry of Health, Ministry of Economy, UkrNDNC;

1.6. Develop methodological support for the implementation of the Regulation by issuing guidelines for the implementation of a set of procedures for all stages of the product life cycle. The implementation period is March 2022. Responsible person - Ministry of Health, Ministry of Economy;

1.7. Develop an action program for the implementation of the Regulation, taking into account the conceptual approaches to the development of the industry and an action plan for the adoption of national standards, providing for the timing of the current "transition" period and the feasibility of their revision. The implementation period is April 2022. Responsible person - Ministry of Health, Ministry of Economy;

1.8. Develop a set of measures for monitoring and evaluating the success of the implementation of the Regulation. The implementation period is June 2022. Responsible person - Ministry of Health, Ministry of Economy.

\section{Discussion of research results}

Based on the analysis of the research results, tendencies in the problems of technical regulation of cosmetic products in the studied foreign countries have been established, namely:

- application of the principles of technical regulation at all stages of the circulation of cosmetic products in the consumer market;

- regulatory legal acts regulate various mechanisms of technical regulation of product turnover, while the general requirement is the mandatory guarantee of product safety for consumer health;

- authorized bodies, for the most part, are represented by government agencies in the field of health care and pharmaceutical activities.

Also, the tendencies of the regulatory policy in relation to $\mathrm{CP}$ for the period of the last three years were established, the actual topic of which is to establish the validity of the declared statements on the functional properties of the product and its belonging to the status of cosmetic.

The range of studies of this work, in comparison with the article by Mohd Riyaz Beg [10], additionally provides a comparative analysis of the practice of technical regulation of products in the cosmetic market of Japan, China and the Russian Federation. It was found that, in contrast to the practice of rationing the status of quasi-drugs in Japan and special-purpose cosmetics in China, recognition of products with joint therapeutic and cosmetic effects in the USA and India, in the EU countries the regulator determines only a cosmetic product. At the same time, the European regulator declares cosmetics with a dual cosmetic and therapeutic effect as a "border product" and is regulated by the relevant guidelines. Strengthening the requirements for product safety and the range of powers of the regulatory authorities, the state assigns the main responsibility for compliance with the regulated norms to the manufacturer of the products.

The results of the analysis of the main provisions of the Technical Regulations for cosmetic products confirm its compliance with the European document. At the same time, the provisions of the European Cosmetic Regulation No. 1223/2009 are fixed, which are not included in the substantive part of the Regulation, the text of the Regulation - the right of the authorized bodies to make changes and additions to its text. This fact will restrict the ability of national authorized bodies to promptly make the necessary changes to the text of the Regulation. The revealed discrepancies in the list of substances prohibited for use (Appendix 2), in our opinion, may negatively affect the objectivity of the assessment of product safety. Also, the Regulation contains references to European normative legal acts that are not 
legitimized in Ukrainian legislation, in particular, Regulation (EC) No. 1272/2008e of the European Parliament of 16.12.2008. These facts require a response from the national regulator in terms of promptly making the necessary changes to the text of the Regulation. In order to minimize potential risks associated with the processes of implementing the norms of European legislation into the normative legal acts of Ukraine and their introduction into the processes of technical regulation of $\mathrm{CP}$, the methodology for implementing the Regulation provides for an appropriate algorithm of actions. Due to the fact that the date of entry into force of the Regulation is August 2022, the timing of the implementation of the relevant organizational and managerial measures is very limited and requires an effective pooling of efforts of all participants in the cosmetic market.

Study limitations was the study of three of the five established factors - organizational and managerial, personnel, regulatory and legal, capable of influencing the implementation of the Regulation. Also into account were taken the influence of the environmental factor.

Prospects for further research are to continue studying the influence of financing factors and the external environment on the processes of implementing the Regulation, as well as developing a quality management system to ensure the safety requirements for perfumery and cosmetic products at all stages of their life cycle.

\section{Conclusions}

Based on the analysis of the practice of regulating $\mathrm{CP}$ turnover, the trends of modern regulatory policy in the cosmetic market in a number of foreign countries have been established; based on the results of studying the requirements of European Cosmetic Regulation No. $1223 / 2009$, the objects of its regulation were identified and systematized. Based on the results of the study of the situation on the regulation of CP turnover in the Ukrainian market, potential risks in the implementation of a regulatory legal act were identified and systematized, and a methodology for its implementation was proposed, which will organizationally ensure the passage of the "transitional" period when meeting the requirements of the regulatory legal act.

\section{Conflict of interests}

The authors declare there is no conflict on interests.

\section{Financing}

The study was conducted without financial support.

\section{References}

1. Annual growth of the global cosmetics market from 2004 to 2020. Available at: https://www.statista.com/statistics/297070/ growth-rate-of-the-global-cosmetics-market/

2. Cosmetics Market. Available at: https:/www.loreal-finance.com/en/annual-report-2020/cosmetics-market-2-1-0/

3. Lebedynets, V. O., Kazakova, I. S. (2020). The analysis and determination of prospects for the development of the market of medicinal cosmetic products in Ukraine. Social Pharmacy in Health Care, 6 (2), 44-60. doi: http://doi.org/10.24959/sphhcj.20.185

4. Pro zatverdzhennia Tekhnichnoho rehlamentu na kosmetychnu produktsiiu (2021). Postanova Kabinetu ministriv Ukrainy No. 65. 20.01.2021. Available at: https://zakon.rada.gov.ua/laws/show/65-2021-\%D0\%BF\#Text

5. Regulation (EC) No 1223/2009 (2009). European parliament and of the council of 30 November 2009 on cosmetic products. Official Journal of the European Union, L 342/59- L 342/209.

6. Kovalova, O. M., Tsyhulova, O. M., Shumilo, O. M., Dieieva, O. O. (2016). Bezpeka kosmetychnykh tovariv v Ukraini. Medyko-pravovi aspekty ta suchasna koniunktura na vnutrishnomu rynku. Kyiv: FOP «Klymenko», 447.

7. Baitsar, R. I., Kordiiaka, Yu. M. (2015). Aktualni problemy ta perspektyvy rozvytku kosmetychnoi haluzi. Visnyk Natsionalnoho universytetu "Lvivska politekhnika". Avtomatyka, vymiriuvannia ta keruvannia, 821, 44-49.

8. Burd, N. B., Heorhiiants, V. A., Polovko, N. P., Hryzodub, O. I. (2016). Likuvalna kosmetyka v Ukraini: realii ta perspektyvy. Farmatsevtychnyi zhurnal, 6, 41-44.

9. Popko, O. V. (2016). Unifikatsiia vymoh tekhnichnoho rehuliuvannia parfumerno-kosmetychnoho rynku Ukrainy z normamy YeS: tovaroznavchi aspekty. Instytutsionalizatsiia protsesiv yevrointehratsii: suspilstvo, ekonomika, administruvannia. Rivne, 198.

10. Beg, M. R. (2020). Cosmetic-Regulations, Research Marketing challenges and global compliance: An overview. doi: http://doi.org/10.31219/osf.io/d8tzu

11. Lores, M., Celeiro, M., Rubio, L., Llompart, M., Garcia-Jares, C. (2018). Extreme cosmetics and borderline products: an analytical-based survey of European regulation compliance. Analytical and Bioanalytical Chemistry, 410 (27), 7085-7102. doi: http://doi.org/10.1007/s00216-018-1312-3

12. Monteiro Rodrigues, L., Fluhr, J. W. (2019). EEMCO Guidance for the in vivo Assessment of Biomechanical Properties of the Human Skin and Its Annexes: Revisiting Instrumentation and Test Modes. Skin Pharmacology and Physiology, 33 (1), 44-60. doi: http://doi.org/10.1159/000504063

13. Amberg, N. (2018). Environmentally conscious consumer behaviour in the cosmetics markets of the United States and Europe. Available at: https://www.researchgate.net/publication/338233673_ENVIRONMENTALLY_CONSCIOUS CONSUMER_BEHAVIOUR_IN_THE_COSMETICS_MARKETS_OF_THE_UNITED_STATES_AND_EUROPE_in_ESZTERHAZY_KA ROLY EGYETEM_GYTONGYOSI_KAROLY ROBERT_CAMPUS_ESZTERHAZY KAROLY_UNIVERSITY_A_TUDOMAN

14. Eixarch, H., Wyness, L., Sibanda, M. (2019). The Regulation of Personalized Cosmetics in the EU. Cosmetics, 6 (2), 29. doi: http://doi.org/10.3390/cosmetics6020029

15. Legislation. Available at: https://ec.europa.eu/growth/sectors/cosmetics/legislation_en cosmetics

16. Inspection of Cosmetics. Available at: https://www.fda.gov/cosmetics/cosmetics-compliance-enforcement/inspection-

17. China Releases New Guidelines on Cosmetic Safety Assessments (2021). Available at: https://www.sgs.com/en/news/ 2021/05/safeguards-06121-china-releases-new-guidelines-on-cosmetic-safety-assessments

18. Hu, A. (2021). CSAR Subsidiary Regulations: China Finalizes Standards for Cosmetic Efficacy Claim Evaluation. Available at: https://cosmetic.chemlinked.com/news/cosmetic-news/csar-subsidiary-regulations-china-finalizes-standards-for-cosmetic-efficacy-claimevaluation 

regulation

19. Hu, A. (2021). Japan Cosmetic Regulation. Available at: https://cosmetic.chemlinked.com/cosmepedia/japan-cosmetic-

20. Guidance on Skin Irritation Asseessment System for Quasi-Drugs and cosmetics safety Asseessment (2021). Available at: https://cosmetic.chemlinked.com/database/view/1241\#documents-list

21. Sarma, P., Kumar, H., Medhi, B. (2017). Cosmetovigilance in India: Need of the day. Indian Journal of Pharmacology, 49 (5), 341-343. Available at: https://www.ncbi.nlm.nih.gov/pmc/articles/PMC5830843/\#idm140273848653776title

22. Pro tekhnichni rehlamenty ta otsinku vidpovidnosti (2015). Zakon Ukrainy No. 124-VIII. 15.01.2015. Available at: https://zakon.rada.gov.ua/laws/show/124-19\#Text

23. Tekhnicheskii reglament Tamozhennogo soiuza «O bezopasnosti parfiumerno-kosmeticheskoi produktsii» TR TS 009/2011 (2011). Available at: https://docs.cntd.ru/document/902303206

24. Kazakova, I., Lebedynets, V. (2020). Analysis of the technical regulation state of cosmetic products turnover in Ukraine. ScienceRise, 2, 39-46. doi: http://doi.org/10.21303/2313-8416.2020.001279

25. Kazakova, I., Lebedynets, V., Kovalenko, S., Kazakova, V. (2021). Research of the activities of the enterprises of the perfume and cosmetic industry of Ukraine. EUREKA: Health Sciences, 2, 44-55. doi: http://doi.org/10.21303/2504-5679.2021.001700

Received date 09.08.2021

Accepted date 20.10.2021

Published date 29.10.2021

Iryna Kazakova*, Postgraduate Student, Department of Management, Economics and Quality Assurance in Pharmacy, National University of Pharmacy, Pushkinska str., 53, Kharkov, Ukraine, 61002

Svitlana Kovalenko, Doctor of Pharmaceutical Sciences, Professor, Head of Department, Department of Management, Economics and Quality Assurance in Pharmacy, National University of Pharmacy, Pushkinska str., 53, Kharkov, Ukraine, 61002

Viacheslav Lebedynets, Doctor of Pharmaceutical Sciences, Professor, Department of Management and Economics of Pharmacy, Institute of Advanced Training of Pharmacy Specialists, National University of Pharmacy, Pushkinska str., 53, Kharkov, Ukraine, 61002

Daria Bondarenko, CEO, Association of market operators of medical devices AMOMD ${ }^{\circledR}$, Simi Sosninykh str., 9, Kyiv, Ukraine, 03134

Viktoriya Kazakova, PhD, Associate Professor, Department of Cosmetology and Aromology, National University of Pharmacy, Pushkinska str., 53, Kharkov, Ukraine, 61002

*Corresponding author: Iryna Kazakova, e-mail: quality@nuph.edu.ua 